\title{
IDEOLOGICAL-ARTISTIC AND GENRE-STYLE PARADIGMS OF WESTERN UKRAINIAN AND EMIGRATION PROSE OF THE 1920S-1930S ${ }^{1}$
}

\section{Maftyn N. V.}

\section{INTRODUCTION}

The literary process of Ukraine was being created in the 1920s and 1930s on both sides of Zbruch, therefore, Western Ukrainian and emigration prose is an organic component of the all-Ukrainian complete literary process the epicenter of which was the search for a style that would meet the requirements of the day and which later would be named by $\mathrm{Yu}$ Sherekh as the "national-organic".

A marked revival of literary life in Western Ukraine dates back to the mid-1920s. The "depression" of postwar worldview is replaced by a passionar dominant. During this period, ideological-thematic directions of prose development were formed, its genre-style palette became richer and bolder - artistic and aesthetic pursuits focused on the artistic achievements of Europe. Western Ukrainian and emigration writing in the 1920s and 1930s, as well as the writers of Soviet Ukraine during the period of ukrainianization, worked on the development of a new artistic outlook aimed at expressivity of expression rather than a descriptivity of the image, outlook that would finally break with the cult of suffering, but instead, would be inspired by the idea of an "active action" - the struggle for Ukraine, its spiritual terrain. The artists of the older generation continue literary work - V. Stefanyk and O. Kobylianska whose authority and artistic achievements made a essential impact on the genre-stylistic and ideological-artistic dimensions of Western prose.

An important feature of the literary process of the late 1920s in the territory of Halychyna (Galicia) and in two emigration centers - Prague and Warsaw - was the "second wave" of emigration. Expatriates from Ukraine - yesterday's leaders of the Ukrainian army, artists, and politicians - continued their mission here. Long before the appearance of the "Garden of Gethsemane" by I. Bahrianyi, the truth about Stalin's concentration camps was told in the novel "Hell on Earth" by Vitalii

\footnotetext{
${ }^{1}$ Мафтин Н. У пошуках «Grand» стилю: західноукраӥнська та еміграційна проза міжвоєнного двадияятиліття. - Івано-Франківськ, 2011, 335 с.
} 
Yurchenko (Yurii Karas-Halynskyi); an alarming ringing sound was made by U. Samchuk's "Maria" "Manuscript writers of people's anger at times of tragic events of state fight of Ukraine were Klym Polishchuk, Yurii Horlis-Horskyi (Yurii Horodianyn-Lisovskyi), Fedir Dudko, Ivan Zubenko; the high spiritual horizons of the "rebellious man", contrary to Stalin's idea of the "screw and wheel" which was spread among Ukrainian people, were affirmed in the prose of the "tragic optimists" - Leonid Mosendz and Yurii Lypa. In Germany, later in France, V. Vynnychenko, who was defamed in the USSR, wrote his philosophical novels known throughout Europe, whose prose also fulfilled the mission of creating the "citadel of Spirit" of the Ukrainian essence, shaped the aesthetic horizons in unison with the thesis, put forward subsequently by M. Khvyliovyi, about psychological orientation to Europe and a departure from the "passive pessimism" of Russian literature.

\section{The humanistic pathos of Western Ukrainian prose of expressionism}

According to the figurative expression of the Polish literary critic Jerzy Kwiatkowski, in the post-war literature of expressionism, "Europe licks war wounds". That is why expressionist style remains the topical style of Western Ukrainian literature in the early 1920s, a style that could most fully operate by the "poetics of pain". From the post-war works of V. Stefanyk (the collection "It is the Earth" (1926)), O. Makovei ("Bloody Field" (1921); Mark Cheremshyna (the collection "The Village Bends" (1925)), Katria Hrynevycheva ("The unbeatable" (1926) - to prose by Myroslav Irchan, Stepan Tudor, O. Turianskyi - in artistic expression pain was coagulated with bloody clots caused by the war and the defeat of the national liberation fight. The strong influence of German and Polish literature (the works of J. Rot, Yu. Vittlin, V. Reimont, S. Zheromskyi, A. Struh, Yu. Kaden-Bandrovskyi, literary circle of Poznan «Zdroj») played not the last role in outbreaks in Western Ukrainian stylistic chart of prominent signs of the "poetics of pain".

Vivid representatives of expressionistic prose among the younger generation of artists in the Western Ukrainian territories were Osyp Turianskyi (novel "Beyond the borders of pain"), Klym Polishchuk (collection "Among the graves and ruins"), Stepan Tudor (collection "Birth"), Myroslav Irchan "Carpathian night", collection "Films of revolution"). A peculiar style syncretism which combines the features of the poetics of expressionism and symbolism is traced in the lyric prose of Yurii Shkrumeliak ("Train of the dead"), Oles Babii (collections of short stories and essays "I am looking for human: essays from war" and "Anger: novellas"), Vasyl Sofroniv-Levytskyi (collection of novellas "Under the 
laughter of war" and "Because war is the war"), fable and lyrical novellas by M. Matiiv-Melnyka (collection "On the other side of the dam", "On the black road").

Undoubtedly, the most comprehensive poetic expressionism in Ukrainian literature along with the works of V. Stefanyk, M. Yatskiv, and K. Polishchuk appeared in the novel by Osyp Turianskyi "Beyond the borders of pain" which was a bestseller of the 1920s. The plot of the novel became tests through which writer went through himself having escaped from the Serbian captivity.

It is no coincidence that the author gave the work another name: "Painting from the abyss." The seven half-dead prisoners who had made up their minds to escape truly stepped beyond the limits of pain, beyond the limits of person's physical and mental capacity. Seven lost in the infinity of snow, being in a situation of terrible struggle of instincts with the spirit, had to pass the exam for the right to at least die as humans. The Turianskyi's characters are constantly feeling the ugly, disgusting breath of death. It is present everywhere: in the white savannah of snow that wrapped the steep mountains, in the dark jaws of abysses, in the hungry eyes of comrades, in their bodies and faces like those of the dead ones. Death is hidden in the immutable freezing of the clouds, chirping on the doomed ones from everywhere. Once in a situation of survival, they compete for life on the level of the darkest instincts, though they resist these instincts wildly trying desperately to preserve humanity.

The blind violinist is the bearer of spiritual light in the novel - the highest truth is visible to him. "There is a sun in life!" - he convinces his friends with strong confidence above the abyss of madness. His visionless eyes see what is invisible for others - the light of faith in Human.

O. Turianskyi made the pain of the human soul and body "a reality" in the word, conveyed its echo through every line of his work. Composition of the novel, which is based on the cinematic montage principle: the contrast of black and white color, the maximum ideological load of visual and auditory images-symbols, was subordinated to it.

In contrast to the leitmotif image of death, the image of the sun and the spiky cornfield, the white house and the garden, the mother and the child appear in the main character's delusions. In the character's fading consciousness, the images become the lifebuoy which designate the archetypal basis of the national spirit. The anti-war, humanistic sounding of the novel, the idea of transforming the world with the power of the human spirit and love, expressionistic poetics put the novel "Beyond the borders of pain" in one level with the best European works on military topics. 
The style searches of Western Ukrainian prose writers in the 1920s and 1930s were vividly realized in Stepan Tudor's experimental works.

In the preface to the 1929 collection, the author declared his desire to tell about the "victorious course of the revolution", and objectively his interest was not so much external facts, events, as the perception of these events by the human psyche - even to its pathological distortions (short stories "Kuna", "Red Smile"). The aesthetic principles of the novel "Mother" are already recorded in the title of the work - "Polissian primitive". Thus, the author sought to emphasize that his work tends not to clear architectural ordering, but to the violation of the "canon" - genre, composition, narrative. In the Tudor's novel, the whole imagery system is subordinated to the artistic realization of the subjective experience of fear and anxiety of the young mother: so black and white, contrasting colors of the nighttime winter landscape as well as artistic detail - moonlight, soft, deceptive, designed to hide the dangerous and evil; the detail that actualizes the phantasmagoric chronotope devoid of time-space coordinates of reality. In the imagery system of the novel, every detail becomes functionally significant (the "grid of shadows", cups of hare tracks with dark blood rings - an image that resonates with the image of the sacrificial bowl).

Tudor, who experimented with the word, proclaiming the "naked movement of the word", was able to sharpen its inner, primal-sensual content. The "language of scream" is the expressionistic one here. We observe a kaleidoscopic combination of sensory, feeling and visual images that "explode".

S. Tudor sought to find a style that would most fully correspond to the rapid course of the new era and his own interest as a scientist - the study of "psychophysical processes". Such an artistic experiment became the story "Milky madness". In style, it is characterized by a synthesis of futurism, dynamism, naturalism and romanticism of vitaism. And in "ornamental decorations" there are also features of impressionistic poetics. Like the futurists, the writer sought to uncover the original conditionality of the sound with mental state, emotions, tried to utterly release, to "bare" the original meaning of the word among the secondary layers. According to the artist, this goal was fulfilled by the NMW, a style trend in his works he had proclaimed - "naked movement of the word". Obviously, in the creative pursuits of prose writer, there was a certain interest in the popular in the interwar period "formal" school of Russian literature studies associated with the group OPOJAZ (ОПОЯЗ) and the Prague linguistic circle "Word and Literature". 
In the early 1920s, the theme of the tragedy and greatness of the Sich Riflemen's Calvary is being understood. Literary youth, who have been lurking around the "Mytus" magazine or was gravitating to it - mostly participants of those tragic events (Yu. Shkrumeliak, V. Bobynskyi, O. Babii, M. Matiiv-Melnyk, V. Sofroniv-Levytskyi) - sought to understand the causes of the defeat of the national liberation fight, to perpetuate the feat of Sich Riflemen. This theme was first and foremost realized in poetry, but the "Mytus" members also developed it in prose. However, great epic canvases about heroic fights of the Galician youth for the statehood of Ukraine appeared later, in the early 1930s. Small forms, mostly essays and lyric prose were characteristic for the early 1920s. Their style is still firmly rooted in symbolism, although elements of the poetics of expressionism are already noticeable.

\section{Historical fiction}

Historical fiction in Halychyna in 1920-1930 becomes "the most psychologically engaged genre" (S. Andrusiv). After all, in times of turbulent change, there is a need to reflect on oneself in history, to turn to the origins of the past of its own people, its heroic pages and, according to E. Smith, "virtues that express national character". The loss of statehood, the painful experience of the defeat of national liberation fight and the need to create a heroic model of behavior for fostering the future, prompted Western Ukrainian writers to turn to the "Golden Age" of Kniazha RusUkraine and the Cossackhood. In Soviet Ukraine, the historical genre was initially subordinated to the development of a topical revolutionary theme and revolutionary motives, and in the past, the events that served as an illustration of the class struggle theory were mostly emphasized. Instead, Western Ukrainian prose of 1920s-1930s was producing a distinctly national historiographical concept of the past.

The primacy of the championship here belonged to a generation of "literary parents" - A. Chaikovskyi, V. Budzynovskyi, Y. Opilskyi, B. Lepkyi.

Andrii Chaikovskyi is traditionally considered to be the founder of Western Ukrainian prose and its canon. It was for young people who had to "prepare for the national consciousness exam", to the "state building", a prose writer wrote in the early twentieth century a number of historical stories and stories: "Cossacks' revenge", "After sister", "He thanked back", "On the leave", "From Tatar captivity". These works and their protagonists, professing a knightly code of honor and love for their native land and their people, have cultivated pride in the heroic past of their native land for many generations, taught to value freedom, cultivate a 
sense of devotion for readers in Ukraine. The historical fiction of A. Chaikovskyi, which focused on the mass reader, offered the reader not only an easy and dynamic adventure story - it performed a certain "therapeutic" effect, helped to overcome the passionary crush that occurred after the defeat of national liberation fight, making actual Cossackhood time as the sacred time of the "golden age", and the behavioral model of his characters was a role model. The creativity of this writer is a dialogue with the past in the course of which a new type of character has emerged the ideal bearer of national virtues. The most complete historiosophical conception of the author-patriot was fully developed in the trilogy "Sahaidachnyi", "Oleksii Korniienko", "The Sun goes down", "Bohdanko", "Colonel Mykhailo Krychevskyi".

Historical themes in Western Ukrainian literature of the 1920s was actively worked out by one of the older art generation respresentative, Viacheslav Budzynovskyi. Tales "Under one mace", "Pidkova's Yesaul", "Blood for blood", "Shahin Herei", "It thunders", "Adventures of Zaporizhia wanderers", "Before the storm", "Cossack Shuba" - a genre of adventurous tales, with mastery constructed plot, interweaving factual material into story's intrigue. At the same time, they are marked by the homogeneity of the plot ("ready plot borrowed from Cooper" M. Rudnytskyi) which reduces the artistry of prose.

The prose of Yulian Opilskyi is marked by the clear tendencies towards the philosophical reading of the past. The plots of his works unfold from the sublime pages of our history (the reign of Sviatoslav and Volodymyr, the struggle against foreign oppressors in the days of Danylo Halytskyi, the spiritual revival in the XVI - XVII centuries), they completely corresponded to the ideological search of Western Ukrainian prose, the need to preserve national identity. The writer addressed to the time of Kyiv Rus in the stories "I go to you" and "Idols will fall" - a fictionalized chronicle of the kniazha era. Yu. Opilskyi's deep erudition allowed him to combine historical truth with compelling authorial fiction. Thus appeared "Under the eagles of Roma" (a tale of the gold mines foundation in the territory of the present Carpathians by the legionaries of Mark Aurelius), "Dance of Pibastus", "Kiss of Ishtar", "Schoolboy from Memphis". Here, the basis of artistic conflict, as, after all, in all works of fiction writer, is the moral confrontation that determines the line of behavior of the characters.

Yu. Opilskyi's historical prose, denoted by a strong philosophical stream, testified a certain evolution of historical genres under the pen of this author in comparison with the works of A. Chaikovskyi, in particular, characteristic for his prose psychological embodiment of the spirit of the era as one of the important components of historical authenticity due to the 
characterization of the characters' worldview. In addition, openness to the motives, images drawn from ancient history reflected the thematic and imaginary spectra of Western Ukrainian fiction.

Among the iconic figures of Ukrainian history, who were particularly attracted to Western Ukrainian prose writers of the 1920s and 1930s, was Ivan Mazepa. It was Bohdan Lepkyi's epopee "Mazepa" that became the most popular work of historical prose in Western Ukraine. The main basis of "Mazepa" is the real events connected with the formation of the Ukrainian-Swedish Union during the Northern War: from the visit of Peter I to Kyiv till the retreat and emigration life of the remains of the UkrainianSwedish troops.

B. Lepkyi's pentalogy is called a novel, an epopee, a fiction chronicle, a historical story cycle. Indeed, the narrative cycle has clear features of the novel-epic and fiction chronicle, because it covers a great connotation of Ukrainian history, tells about events that are significant in the fate of the people. The panorama of the image of life in Ukraine in the Hetmanshchyna period and the historical probability/ truth вірогідності of the reproduction of the day, the author achieved largely due to the use of travel. The chronotope of the road made possible a detailed depiction of both the political situation in Ukraine at that time and the situation of the subjugated people. The descriptions of crimes committed by the Moscow people against the Ukrainian civilians and the Cossack army are also subordinated to this purpose: the writer tried to bring the reader to the idea of the need to protect his own freedom. The culmination of the whole cycle is "Baturyn," a story about the heroic defense of the Hetman's residence and the depiction of the horrific massacre committed by Menshykov in the betrayed city. Before writing the novel, the author carried out a deep preparatory work: at that time, B. Lepkyi studied from the hetman universals, the messages of Peter I, the letters of Charles XII, historical monographs. Therefore, even the author's speculation regarding the fate of the characters in pentalogy is clearly subordinated to the historical truth, documentary evidence of certain events. It is important that these events be depicted in the novel at an angle of philosophical understanding of history, the causes of the defeat of Ukrainians in the national liberation war. By rehabilitating the name of the hetman under anathema, the author broke the imperial tradition in treating both the image of Mazepa and the battle under Poltava.

The central idea of pentalogy is connected with the image of the hetman - the idea of Ukraine's independence, statehood as a pledge of freedom and the opportunity to realize oneself for the whole nation and for the individual. The novel, having preserved the features of historical fiction (chronotope of the road, dynamic plot, interestingly modeled lines of 
private life), is a distinctly historiosophical work: the author was able to read the future in the past, so his work sounded a precaution against the genocide of the Ukrainian people in the twentieth century.

The originality of style and innovative approaches to historical subjects are distinguished at the backdrop of Western Ukrainian fiction works by Katria Hrynevycheva. Her "Six-winger" and "Helmets in the sun" belong chronologically to the end of the 1920s, but due to the peculiarities of style, originality of the compositional solution, the specificity of the imagecreating, are more organically perceived in the context of the artistic achievements of the next decade.

The peculiarity of the composition of the dilogy is fragmentation, mosaicism: the work consists of separate completed novellas which interwove shimmering into each other and create a holistic, saturated with vivid artistic images picture of antiquity. The unifying compositional beginning was the common image of kniaz Roman, a hero portrayed in the style of the Norman sagas. Kniaz Roman goes the way from a young man who is thirsty for fierce battles to a warrior-politician whose rule has left a steady footprint in the history of Ukrainian land.

On the canvas of the historical era, the writer draws amazing patterns of a neo-mythical vision of the world that dates back to Slavic times.

Historical fiction of A. Chaikovskyi, V. Budzynovskyi, Y. Opilskyi, B. Lepkyi, K. Hrynevycheva, together with historical fiction of the 1930's, created a single "hypertext" in which works of greater and lesser artistic value were combined by common ideological dominants, historiosophical concepts, searches of the character of a new type - strong-willed person. Thus, literature became the birthplace of the national spirit, grafted faith in the triumph of the state idea.

\section{The young literary generation of the $1930 \mathrm{~s}$ and its creative credo}

In the 1930s, Halychyna's literary life is revived. At those times, in the Soviet Union, the "terrible abyss of the thirties" had fallen back (Yu. Sherekh), so the West Ukraine became a bridgehead against assimilation and ethnocide; literature, created in its territory, confirmed the idea of Ukraine spiritual, state, the idea of formation of national cultural consciousness.

Writers, united around the "Vistnyk" magazine, combined this task with the idea of turning literature into the banner under which an entire nation would be united. Catholic-trend artists emphasized the "eternal" Christian values. In addition, many artists (authors of the journals "My (We)", "Nazustrich (Towards)") searched for their own paths, independent of any ideology. In the prose of this period, in comparison with the 1920s, 
the "recurrences" of symbolism became less noticeable, and the style palette was dominated by neo-romanticism, impressionism, and baroque (Yu. Lypa "Cossacks in Moskoviia", Yu. Kosach "Charming Ukraine", "Khmelnytskyi's Rubicon").

The instruction of "visnykivtsi" to combine the national idea with high art was embodied in the novel by Yu. Lypa "Cossacks in Moskoviia" whose characters in search of their destination go through all circles of "Moscow hell". By genre, this is a kind of historical and adventurous work, the compositional basis of which is the model of character's challenge. However, the ideological imperative of Yurii Lypa's work is motivated by his historiosophical concept, understanding of Ukraine's past and future, its powerful spiritual potential. The idea of the work also identified a distinct neo-baroque style dominant.

The central characters who were destined to be challenged by the "antiworld" are not accidentally a merchant (Hryhorii Trembetskyi), a Cossack (Petro Sokolets-Viazhevych) and a philosopher (Symeon LatkaStarushych). After all, merchant, warrior and scientist are not just "representatives of the Ukrainian world of that time". They are the bearers of ancient Ukrainian vital energy inherited from the powerful triad of Ukrainian ethnopsychology - the Trypillian bakery, Gothic and Hellenic principles.

The neo-baroque style provided the author with the full realization of the prominent historiosophical concepts connected with the understanding of the historical destination of Ukraine and Ukrainian man. The idiostyle of the novel "Cossacks in Moskoviia" absorbed not only Baroque rhetoric but also symbolism, topical associations of Ukrainian Baroque thinking, emphasized the antithetical structure of being, and, most importantly, the powerful energy of action, act and energy.

High artistic skill and national idea characterize the works of Leonid Mosendz. The central theme of his collection "The obedient man" is the liberation war of the Ukrainian people in 1918-1921, the tempering of a new man in this fight, an active one, capable of great action, strong-willed, holistic, free from the inferiority complex, sentimental disenchantment. The author affirms with the mouth of the narrator, David, from the collection "The obedient man" that "the only vital basis is action". Complete and brave are the characters of the novels "On formation", "Brother", "Berladnyk (Brodnici)". Some exotic plots of the stories "Big Bow" and "The Return of Cossack Michael Smiles" are intended to express problem, raised by the author, of returning to his native roots by the blood call. The gallery of strong-willed and courageous images, however, already in another thematic and temporal perspective, the author 
continued in the collection "Payback". Its themes are mainly related to medieval Europe. However, at the heart of the conflicts of works placed here is the same impulse to act. With his collections of "The obedient man" and "Payback", the author continued the best traditions of Ukrainian novella studies while updating the classic genre in accordance with the requirements of the time.

L. Mosendz's greatest work was the novel, "The last prophet" on which the writer had been working for eleven years, but which was not completed (the work began in the mid-1930s, fragments were published in the "Vistnyk" during 1937-1939, fully published in Toronto in 1960). In "The last prophet", the author "through the prism of the Bible and the history of another people, tries to understand the historical perspective of his nation". (I. Nabytovych). Turning to the biblical story, the Ukrainian novelist created a highly fictional novel that continued the traditions started by I. Franko, Lesia Ukrainka, H. Khotkevych.

The fragmentary composition of the work is integral due to the central image - the figure of John the Baptist (Jehohanan). The axis of the plot is the search first of Jehohanan's parents - Zechariah and Eliseba, and subsequently by himself to answer the question of the meaning of being, which is to wait for the coming of the Messiah and to serve him.

Among the writers who focused on the best achievements of the literary art of Europe while looking for their original ways to master artistic space, Yurii Kosach singles out stylistically.

His novel "Khmelnytskyi's Rubicon" is a brilliant realization in the ideological and artistic structure of an artwork of his own historiosophical concept. The "optimistic historicism" of the author's artistic thinking clearly manifests his Eurocentric position, understanding of the cultural tradition of Ukraine as a component of European cultural discourse. The work is written in the spirit of neo-baroque aesthetics.

The novel "Khmelnytskyi's Rubicon" also testified to the changes that took place in Western Ukrainian and emigration prose in the late 1930's in the historical fiction genre: a kind of "shift" from accentuation of adventure to "truth of fact" and expression of a historiosophical concept.

$\mathrm{Yu}$. Kosach also abandoned techniques of compositional organization of the work traditional for Ukrainian historical fiction, in particular, the road chronotope. After all, in the baroque work, the "story of the birth of the hero" occurs precisely in the period of relative static, a kind of stop on the road and immersion into "self-knowledge". The same situation is observed in Yu. Kosach's novel: after the end of victorious military actions near Dunkirk, the Cossack corps entered the port of Danzig and is awaiting for a decision of its further destiny. Kosach was able to skillfully "focus" 
all European events and their echoes around the figure of the Ukrainian hetman, then only the captain of the French army. Successful finding of the author became a through metaphor of the game acting as a compositional axis and at the same time permeating all levels of poetic structures of the novel. The novel, in fact, begins with the episode of the chess game. In the novel all the central figures are "playing chess" - after all, fate, peace and war depend on the result of the party played by spies of the Wolf League, agents of the Polish king, the mighty courts of Vienna and Madrid, informants of the Polish Queen Maria Gonzaga. Chess party and chessboard is a crystal lattice of micro and macrostructures of a novel, an image-rhizome that permeates the fabric of a work triggering the clarification of its ideas and the specificity of the image-making. And even the distant Ukrainian land on the Gondius map appears to the players as a "colorful chessboard". The echo of the through metaphor is felt in every turn of the plot.

The Europeanism of Yurii Kosach's artistic thinking first of all appeared in his Eurocentricism in the novel - the author is still "looking for Ukraine in Europe" because he does not think it outside the cultural and historical European discourse.

This vector of artistic thinking is clearly marked the creativity of Pragueian Natalena Koroleva, the heiress of the ancient Spanish family of Lacerda and the Polish Counts Dunin-Borkowskis.

The thematic and ideological and artistic level artistic world of Natalena Koroleva were clearly influenced by the formation of writer's ideology in the system of Western European cultural values. The ideological and artistic vector of the Koroleva's texts is directed through the lens of the "eternal law" of Christian doctrine - to solve the dilemma of good and evil confronting the forces of light and darkness, which is inherent in the whole concept of the development of the European cultural paradigm. This is also evidenced by Natalena Koroleva's first novel, "1313", published in 1935. The stylistic manner of the work, which the author herself defined as the "Ukrainian Gothic style", is a striking example of neo-romanticism. Neo-romantics as a belief in the height of human spirit, as the affirmation of eternal heroics and the need for the beautiful, as the art of experiencing the tragedy of human being and comprehending its greatness, is the philosophical basis of this work.

In 1939, Natalena Koroleva began to publish in "Dzvony (Bells)" a new historical story (another definition - a novel), "Quid est veritas?" ("What is the truth?"). However, only two chapters were printed at that time - "From the great days" and "Movements of the element". The author noted that this is the beginning of a great work. The story was fully 
published as early as 1961 in Chicago. In this work, the writer turned to the history of Judea of Pontius Pilate. Building the artistic world in the coordinates of the time of Messiah's coming, showing the spread of the light of His teaching, the writer focused on the images of Pontius Pilate and Mary Magdalen. To create her own artistic version of the search for the answer to the age-old question, the author used not only the events described in Scripture, but also the motives of Catalan and Provence legends, the mythopoetics of Celtic mythology. From the cruel procurator of Judea to the Christian Saint Marius - her Pilate goes through such a path in the search for the truth. Natalena Koroleva actively used in the structure of the story Christian motives of miracle, in particular the resurrection. The work is saturated with Christian symbol-images (water as a symbol of the Sacrament of Baptism, a ship as a symbol of eternal life, a flower of passionflower as a symbol of the Passion of Christ), the central among which is one of the eternal images - the image of the Holy Grail.

Natalena Koroleva's creativity and destiny are a striking example of the artist's identity - the integrity of his personal character and the nature of his work. In the works of the writer she embodies her worldview imperative, which was realized in the theocentricity and high Christian values rooted in the European cultural tradition and active life position. That is why the characters of prose by Natalena Koroleva are always looking for ways to the Truth, Ideal, and God.

Among the thematic diversity of Galician prose of the 1930s, the theme of the Ukrainian revolution, the struggle for statehood continues to be one of the most prominent. A powerful anti-Bolshevik charge was carried by the works of Yu. Horlis-Horskyi ("Kholodnyi Yar", "Otaman Khmara", "Red Thistle") and V. Yurchenko ("Red Chad fumes", "Ways to Solovky") - emigrant writers from Naddnipriany Ukraine, who escaped from the red genocide hell.

V. Yurchenko's trilogy "Hell on Earth" has clear features of the detective-adventure genre. However, the value of this work lies primarily in its revelatory documentary directed against the Bolshevik-Stalin genocide in Ukraine. After being published in the publishing house "Chervona Kalyna" (1933), the work immediately became a real best-seller in Halychyna: for the author was one of the first to tell about the horrific realities of the "Soviet paradise" which became a real hell for millions. At the same time, the work asserted an invincible belief in life, in the national idea, in Ukraine. It is a text with an interesting plot and at the same time a document of the day: it is characterized by a combination of revelatory pathos with adventurous elements. There are also clear signs of the memoir genre, because the author was a living witness to the events described. In 
his work V. Yurchenko not only affirmed the human will to life: he showed a man full of active action - active love for Ukraine.

A tribute to the literary fashion that went "via Warsaw" was the attraction of Galician prose writers (Yu. Kosach, I. Zubenko, S. OlshenkoVilkha, M. Kapii and others) with the mysticism cultivated by the Polish surrealists (M. Khoromanskyi, P. Khoinovskyi, V. Gombrovych). Many of the novels of this period are characterized by the artificiality ("sharpness") of the intrigue - the generation of young Western Ukrainian novelists tried to find their own solution to the classic form by putting the whims of moods, feelings and everyday paradoxes into the basis of the novelistic composition. A striking example of such artistic pursuits are the novels by Yaroslav Kurdydyk "The Neighbor from the Gothic Villa", and Iryna Vilde "The chimeric Химерне heart". A bitter grimace of life instead of a happy smile of love is what the characters of these works face. Happiness is just a mirage. Unexpected encounters on the road of life reveal to man the fullness of being: both the joy of the world and its enduring sadness. The pretty girl who falls in love with the protagonist of the short story by Ya. Kurdydyk is dumb. In the novel by Iryna Vilde, the situation is also dramatized by the fact that the deaf-mute beauty, who has taken over the heart of opera singer Alexi, is mentally retarded.

Even the theme of Sich Riflemen Calvary is experiencing new approaches. For example, Anatol Kurdydyk referring to the popular in Western Ukrainian literary discourse plot, on the basis of which lies the Sich Riflemen Christmas carol, chooses the fragmentary-mosaic principle of the composition, focusing not on the eventful side, but on the mood of the work. The novel "Six Easter eggs" is designed as flashbacks-memories of an old mother, who draws Easter eggs on Easter Friday for her six sons who died for Ukraine. The compositional basis of the work in which the ideological dominant is rooted is the leitmotif details that acquire a deep semantic load: six Easter eggs, their ornaments become for the gray-haired mother the world of her sons' childhood and adolescence.

An interesting page of Western Ukrainian prose of the 1930s was the work of Vasyl Karkhut, a well-known physician, herbalist whose lifelong feat would remain an example of ardent and active love for Ukraine (V. Karkhut served nine years of hard labor for his cooperation with the UPA (Ukrainian Insurgent Army)). The subtle observance of the true connoisseur of the environment, the love of nature, deep humanism and the ability to honestly and spiritually tell the life of birds and animals (collections "Wheat thicket", "Noise from behind us") elevate the Ukrainian author's animalistic narrative to the level of creativity of the best writers-natural scientists, E. Seton-Thompson, J.-R. Kipling, J. London. 
In the 1930s, Western prose writers successfully mastered the fantasy genres, in particular, Myroslav Kapii published a story about the journey of the Earthlings to the planet Mars ("The Land of Blue Orchids"), turned to fantasy also in small genres ("Incredible stories"). There are elements of fantasy in the stories by Ivan Cherniava (Emil Kitsyla) "In the East - we are" and "People with black palate".

Historical prose in its various genres also remains popular. For this prose, the current trends in historical fiction in the late 1920s continue to be relevant: the pursuit of documentaryism, the expression of an "ideological code", the overcoming of the romantic stream in the plot and image-making. Historical fiction continues to nourish the "historicism of contemporary thinking" which is throbbing in all aspects of Halychyna's cultural life, with a strong emphasis on the desire to realize state-building imperatives. The idea of Ukrainian statehood pervades the historical works of Antin Lototskyi ("Knight in black velvet", "Kuzhil and the sword", "Glory of kniaz") and Vasyl Birchak ("Volodar Rostyslavovych", "Against the law"), although at the level of artistic and stylistic this prose is a typical production of mass culture. Among the authors who have successfully worked in the genre of historical tale, Galician criticism distinguished I. Fylypchak, appreciating his prose for the "technique of structure" and "interesting narration". Chronotope of his works includes ancient kniaz times and the times of Cossacks: "Kniahynia Romanova", "For Xiang", "The builder of the state", "Ivanko Berladnyk" ("Ruined power"), "Kulchytskyi, the hero of Vienna".

Historical fiction by Semen Ordovskyi (real name - Hryhir Luzhnytskyi), a well-known figure of the literary and artistic movement in Halychyna of the interwar period, one of the founders of the "Logos" literary group, a talented critic, a playwright, a prose writer still did not lose its artistic significance and high ideological force.

Most clearly the talent of the prose writer was revealed in the genre of adventure-historical story, which he addressed in the late 1930s. The stories "The Crimson Cross", "The Silver Skull", "The Black Hegumeness" constitute a kind of trilogy: they are connected thematically; here act the same main characters. Historical basis for the author to write the trilogy were the fragments of old documents about the existence in the troops of Bohdan Khmelnytskyi secret intelligence department (chornokyreinyky). Therefore, we can talk about the orientation of the author's artistic thinking to the observance of historical facts, facts of the document. S. Ordivskyi was able to combine a perfectly elaborated form of "sensational" story with a deep understanding of Ukrainian history, fascinating intrigue - with a powerful ideological dominant. The 
originality of the author's style is due to the creative reception by the author of the best features of Ukrainian fiction and the neo-romantic worldview as an expression of passionarity. Resurrecting on the pages of the trilogy the figures who remained in the shadow of history, the author described the adventures of true Ukrainian knights, aristocrats of the spirit who without hesitation give their life for the homeland.

And although the plots of these stories are unfolded on a solid frame of ideologuemmes, it does not diminish their artistic value: here the spirit of the era is recreated with talent, a fascinating intrigue is observed, the dynamics of events appropriate to the adventure genre are kept, the intertwining of human fates is artistically convincingly drawn, the depth of feelings is revealed.

\section{Alternative style directions}

The literary life of Lviv in the 1930s, the desire to update the style space could not but be influenced by the general artistic atmosphere, in particular, and the powerful creative aura created by the emigrant artists who "brought a new impulse to the Galician artistic life" (S. Hordynskyi). After all, in the 1920s-1930s, such well-known artists as P. Kholodnyi, Yu. Mahalevskyi, V. Kryzhanivskyi, M. Butovych, P. Kovzhun worked here. Since 1931, AIUA (Association of Independent Ukrainian Artists) has been actively functioning in Lviv organizing a series of resonant exhibitions in Europe. Stephaniia Hebus' woodcuts, enamels by Mariia Dolnytska, battalistic paintings by Leonid Perfetskyi, architectural designs by Oleksandr Lushpynskyi, Roman Hritsai, Yevhen Nahirnyi, graphics by Pavlo Kovzhun, and the carvings by Mykhailo Parashchuk "sparkled with their individuality and national identity". (S. Hordynskyi) Here the artistic ideas of M. Boichuk and O. Arkhypenko, Western European style innovations were creatively perceived. Fine arts also promoted urban themes that found expression in the art of words, most clearly embodied in the poetry of B.-I. Antonych and in stylistic experiments of prose by B. Nyzhankivskyi, Zh. Protsyshyn, and Z. Tarnavskyi. These style searches were also influenced by the innovative literature of Poland, in particular the Krakow avant-garde and the prose of the great innovators: S. Vitkevych, V. Gombrowicz, M. Khoromanskyi, Z. Hrabowski, B. Schulz.

A clear testimony to such searches is the unfinished prose of B.-I. Antonych. It is noteworthy that he first saw his vocation as an artist in the realization of the "need to learn a European worldview" (articles "Primitive Europeanization", "National art", "How to understand poetry"). In the unfinished novel "On the other bank," which was conceived at the 
beginning of his creative work (a fragment of the work was published in the magazine "Dazhbog" in 1932), the eponymous story, which is a continuation of the novel, the prose fragment "Three mandolins", artist is mostly approaching to existentialism. The author's "jumps through the gap of information" give reason to believe that the narrative of the novel tends to flow of consciousness. This narrative strategy is also reflected in the compositional feature of the work - the extra-narrative narrative when the emphasis is shifted from the event sphere to the impressionistic rendering of the nuances of the character's spiritual life. The novel testifies to the author's attempt to philosophically contemplate life, to perceive it as a flow of life. This is also indicated by the rather eloquent name of the work as well as the symbolic images of the river and the old bridge that connects its two banks. The world of the experiential experience of the characters of Antonych's work is bipolar: life fully exists in it as an unsolved mystery and death as a behind-mirror, a continuation of the mystery that is tied on this shore.

Thus, in the 1930s, Western literature came to a fertile period for experiments and searches, and for the new ways that S. Hordynskyi mentioned: the writer "cannot be justified by the nobility of his ideas when his works lack beauty". 2

The active search for "beauty", the attitude to the art of word as a game, the attempt to break free from the ideological differentiate the creativity of the Lviv art group "Twelve" (1935). Bohdan Nyzhankivskyi, Vasyl Tkachuk, Ivan Kernytskyi, Anatol Kurdydyk, Yaroslav Kurdydyk, Ivan Cherniava, Zenon Tarnavskyi, Vladyslav Kovalchuk, Fed Tryndyk, Roman Antonovych, Karlo Mulkevych (though there were many more creative figures who rotated in the "Twelve" power field) were the members of this "club-friendly association" the founder of which was A. Kurdydyk. Representatives of the group considered Mykola Holubets their spiritual father. Young poets and prose writers were united not only by the "bohemian-café way of creative life", but above all by the understanding of the creative process as a game with style and form as well as urban motifs that were not typical of Western Ukrainian prose.

Prose by B. Nyzhankivskyi presented to the group the original artistic face; he was the creator of the genre of batiary stories, which testified to the expansion of thematic horizons of Western Ukrainian prose and updating of its genre palette. Novels from the collection "Street" testified to the renewal of thematic horizons of Western Ukrainian prose (in

\footnotetext{
${ }^{2}$ Гординський С. Комплекс оселедияя.- Ми1935, №4, с. 155.
} 
particular, they emphasized urban themes) as well as those form-creating changes that clearly indicated the pulsation of new rhythms in its style field which were characteristic of the surrealism of intuitivism and deformation of the artistic image.

The search for "great style", mastering the form is represented by the work of Vasyl Sofroniv-Levytskyi. The editor of "The Chronicle of Chervona Kalyna" actively experimented with the genre of novella expanding its thematic spectrum and diversifying the plot structures (collection "July poison"). At that time reputable Galician critics (M. Rudnytskyi, O. Dniprovskyi, M. Hnatyshak) unanimously recognized his mastery of the novella technique and the European manner of writing. A real artistic event in Halychyna was the publication in 1934 of the collection of novellas by V. Sofroniv-Levytskyi "July Poison" which testified the talent of a bright novelist, author of sophisticated, sometimes even a few "sharp" (Yu. Klynovyi) plots, often constructed on the "psychological marvels": the author seeks to explore the subtle boundary that separates the real from the unreal, the consciousness from the subconscious. Testimony to this is the novella "Klikusha" whose character lost his mind because of a horrific encounter with grown wild dogs in a village ruined by the army.

Close to its genre-style parameters to the novelty of V. SofronivLevytskyi is a small prose by Iryna Vilde. In 1936 separate works of the writer were published: the collection of novellas "Chimeric heart", the story cycle "Butterflies on studs", "The eight strikes". In 1939 the third part of the cycle is published, "Adult children". Lviv and Kolomyia magazines constantly publish novels, sketches, literary-critical essays of the young author. Also popular was the story "Windows apart" which was published on the pages of "Women's Destiny". People speak, write, criticize and praise Iryna Vilde. The secret of such a success of the writer is in the special, sincere and trusting tone communicated by her heroines with the reader, in the ability of the author to easily draw the novella's plot from the everyday life of an ordinary woman.

In her early works, Iryna Vilde was able to create a unique figurative world. It reflected not so much the conflicts of the era as life-long problems of human existence (happiness, tolerance in human relations, harmony of married life, longing for the beautiful). In most of the early writer's works, the problem of women's happiness, the problem of becoming a woman as a person, is raised.

The second group of works by Iryna Vilde is the novellas, which break the problem of eternal longing of the bizarre human heart for the beauty, non-everyday life and illusory nature of such unprecedented non-everyday happiness ("Traveler", "Adventure of Uliana", "Gift to the poorest", 
"Chimerical heart", "Everywhere is the same", "Tower of Babel", "Pianist", "Oriental melody", "You", "Blanca"). It is in these works that the modern style of writing of the young writer, the genre peculiarity of her novellas, and features of image-making are fully revealed. The author skillfully uses the symbolism of colors and sounds ("Chimeric Heart", "Tower of Babel", "Pianist"), uses an internal plot instead of a fable, eventfulness based on the collision of different reflections, experimenting with narrative structures. Often her works are monologic, close to the "stream of consciousness".

At the same time, in the early prose of Iryna Vilde, the problem of national dignity is also raised (the novels "I can't", "Enough", "Rescued", "Black council", "Decisive conversation", stories "Butterflies on studs", "The eight strikes", "Adult children").

A significant number of early novels by Iryna Vilde have a "sharp" plot that, like in the works of V. Sofroniv-Levytskyi, is built on psychological "oddities" or unusual, with a distinct detective tone, cases. These are novellas: "Theft", "Kiss", "Crime of Dr. Komarivskyi", "The ones with chestnut hair", "Mysterious couple", "Boy from protection", "Panna Larysa", "Panna Melia". Here, the author experiments with the classic architecture of the genre, trying to combine a rather small, artificial intrigue with a masterfully accomplished novella composition.

Iryna Vilde's novellas are characterized by a close-psychological vision of the disturbances of her characters' slightest thoughts and feelings, which at the level of style is manifested in the use of an internal monologue. The young writer made a definite contribution to the development of the novella genre. Keeping its basic "configuration", she often experimented with structural elements, gender tense, the narrative level of the novella's poetics.

In the literature of the 1930s, lyric prose is still popular among women's authors, remains popular (S. Parfanovych, Ya. Lahodynska, O. Tsehelska). These are without fable, mosaic patterns of mood or monologue-confession, lyrical revelation framed as poetry in prose. This is genre of art where Dariia Vikonska's creative work is distinguished.

The writer belonged to the authors who tried to continue the traditions of O. Kobylianska. However, if Katria Hrynevycheva, Halyna Zhurba and Iryna Vilde first of all reciprocated the ideas of O. Kobylianska about the cultural function of women, their role in the establishment of a modern nation, then the prose of Dariia Vikonska appears as a kind of continuation of the "new Apollonian myth of the new woman" created by Kobylianska.

The femininity of D. Vikonska's writing is manifested in the cultivation of melancholy beauty, sentimental contemplation, sensuality. Through the prism of the individual style of the writer palimpsestly comes 
the attempt to reproduce the imagery and mood of the lyrical prose of her literary idol. In poetry in prose of D. Vikonska we can quite clearly see the features of the secessionist style ${ }^{3}$ : pastel color associations, metaphorical associative-emotional images, lyrical tone dominate here. The cult of "atre nouveau" ("new art"), combined with narcissism, a pose of artistry, aesthetization and fetishization of feelings are characteristic for the collection of sketches by D. Vikonska "Paradise apple tree". The title of the collection shows not so much the archetypal symbolism of sin and pleasure as the provocative nature of the eroticism aesthetized in the art of erotism secession. The composition of the collection also emphasizes the author's clear orientation to the ornamental decoration of this style: it consists of separate "chords" - mood sketches which remind the flow of thoughts filled with impressionistic psychologism, eroticism, and have the form of dialogues and painting visions. Dialogues about the essence of love and the purpose of the woman seem to continue in the force field embodied in the past by O. Kobylianska in her texts and the epistolary of the "platonic utopia of perfect communication" (T. Hundorova).

\section{CONCLUSIONS}

The diagram of the literary process in the Western Ukrainian lands of 1914s-1939s highlights certain features of the thematic, style and genre constant. First, the prose of the early $1920 \mathrm{~s}$ as a post-traumatic phenomenon of the post-war era tends to gravitate to the aesthetics of expressionism. It is devoted mainly to the anti-militant topics and is imbued with the motifs of "Sich Riflemen Calvary". Secondly, the Narodnyky discourse of the traditional romantic historical narrative of nature has not exhausted itself, though experimental works appear in the field of historical fiction at this time. Thirdly, it was in the thirties that alternative style trends emerged in the creative work of the young literary generation.

Western Ukrainian and immigrant prose of 1920s-1930s was aimed at affirming the idea of state and spiritual Ukraine in the whole genre and style diversity of its manifestations and ideological involvement. Renewed realism, which appeared completely in U. Samchuk's prose and gave an interesting synthesis with psychological impressionism in the works of H. Zhurba, N. Koroleva's neo-romanticism and neo-Gothic, bright stylistic amalgam of neo-romanticism, romanticism of Vitaism, impressionism in the prose of "tragic optimists" Yu. Lypa and L. Mosendz, "tragic Europeanism" of artistic searches of Yu. Kosach, utopian and

${ }^{3}$ Мафтин Н. Гендерна утопія $і$ код самості в західноукраїнській прозі 30-х років ХХ століття. Слово і час, 2009, № 6, с.316-322. 
philosophical novels by V. Vynnychenko, and historical fiction of the authors-traditionalists, and not equally so clearly biased idea of national literary experimentation efforts of literary bohemia (I. Cherniava, B. Nyzhankivskyi, V. Sofroniv-Levytskyi and others) suggest national consolidating narrative of Ukrainian literature, which was created on the territory of great Ukraine prior to the great mass arrests as well as outside Ukraine, in Halychyna and emigration centers: Prague, Warsaw, Berlin, and later in the diaspora; narrative that opposed the unifying socialist realist rhetoric of literature.

\section{SUMMARY}

The paper deals with the ideological-thematic and genre-style palette of Western Ukrainian and emigration prose of 1920s-1930s of XX century. It is proved that in a variety of creative pursuits a new "national organic" (Y. Sherekh) style was being born determined by the idea of the struggle for the "state of the word" - spiritual Ukraine, which in the conditions of loss of statehood would become a springboard of resistance to the Russian Soviet occupation. Such passionary dominance, however, does not simplify the variety of artistic prose of the period: it is combined with the actively implemented in the artistic practice of the authors instruction to reach European artistic horizons.

\section{REFERENCES}

1. Андрусів С. Модус національної ідентичності: Львівський текст 30-х років ХХ століття. - Львів, 2000, 340 с.

2. Гординський С. Комплекс оселедияя. - Ми1935, № 4, с. 155.

3. Мафтин Н. Гендерна утопія і код самості в західноукраӥнській прозі 30-х років ХХ століття. Слово і час, 2009, № 6, с. 316-322.

4. Мафтин Н. У пошуках "Grand» стилю: західноукраїнська та еміграчійна проза міжвоєнного двадиятиліття. - Івано-Франківськ, 2011, 335 c.

\section{Information about the author: Maftyn N. V., Doctor of Philology,} Professor at the Department of Ukrainian Literature, Vasyl Stefanyk Precarpathian National University 57, Shevchenko str., Ivano-Frankivsk, 76018, Ukraine 